\title{
Strategic Development of the Innovative Infrastructure of a Region
}

\author{
Kashitsyna Tatiana ${ }^{1} \&$ Berkovich Margarita ${ }^{2}$ \\ ${ }^{1}$ Vladimir State University, Vladimir, Russia \\ ${ }^{2}$ Kostroma State Technological University, Kostroma, Russia \\ Correspondence: Kashitsyna Tatiana Nikolaevna, Management and Marketing Department, Vladimir State \\ University, Vladimir, 600000, Russia. Tel: 79-15-755-0417. E-mail: kashicina@yandex.ru
}

Received: August 8, 2014 Accepted: August 21, 2014 Online Published: October 30, 2014

doi:10.5539/ass.v10n21p145 URL: http://dx.doi.org/10.5539/ass.v10n21p145

\begin{abstract}
This article emphasizes the importance of innovative infrastructure in the development of various countries. The current state and problems of the innovative infrastructure implemented in Russia are determined and the results of its underestimation are indicated. The article includes the author's methods of estimation of the innovative infrastructure development within a region, since the level of development of the innovative infrastructure and the quality of its' performance trigger not only the success of implementation, costs and efficiency of the innovative reformations in a country, but also the feasibility of any innovation project. The recommended indicators of the development of a regional innovative infrastructure are presented.

The encouragement of innovative activities is quite literally the highest priority course of the economic policy of the state, as long as the level of science and technology development mainly influences on the long-term strategic advantages of a country; the potential development of a state largely depends on the innovative infrastructure.
\end{abstract}

Keywords: innovative development, innovative infrastructure, region

\section{Introduction}

The efficiency of the innovative infrastructure system in Russia is mostly caused by the efficiency of its' components - regional innovative systems. Everybody unconditionally admits the need of development (enhancement, optimization etc.), however there is no unanimity on what needs to be changed and how it needs to be changed. Currently everybody (politicians, managers and the officials of the very innovation system) clearly understands that the enhancements must be goal-oriented and reasonable, so there is a need to introduce a model of a region's innovative infrastructure development - a document that specifies the basic rules, stages and events.

Despite the fact that governmental authorities nowadays emphasize the need in development of the innovative infrastructure, the role of innovation in economy is so far negligible (Table 1).

Table 1. Indicators of innovation activity in Russian Federation and other countries in 2012

\begin{tabular}{lccc}
\hline \multicolumn{1}{c}{ Indicator } & Russia & Germany & Finland \\
\hline $\begin{array}{l}\text { Number of personnel in scientific research and development per 10 000 } \\
\text { economy employees, persons (Filimonenkova, Kupreenko, \& Shvarova, }\end{array}$ & 122 & 137 & 217 \\
2014 ) & & & \\
Share of companies applying technological innovation in 2012 in the & 10 & 80 & 62 \\
sampling frame, \% (Bortnik, Zinov, Sorokina, \& Kotsyubinsky, 2013) & & 2.88 & 3.78 \\
$\begin{array}{l}\text { Internal expenses on research and development, \% to GDP in 2012 } \\
\text { (Filimonenkova, Kupreenko, \& Shvarova, 2014) }\end{array}$ & \multirow{2}{*}{1.12} & & \\
\hline
\end{tabular}

The analysis of commitment to innovation and application of the advanced technology within the economy of Russian Federation demonstrates that businesses' perceptivity to the technological innovation remains low. It is necessary to develop the demand for innovation and keep the level of commoditization low, as well implement 
the innovative ideas and enhance the new products, services and processes going on in the market and practically utilized.

The upgrade of commitment to innovation largely depends on the complex factors that affect the possibility of innovation activities development in the country in general or in a particular region, so it is essential to develop and sustain the innovative infrastructure of a region.

Innovative infrastructure appears as the foundation of the new economy. A sustainable innovative infrastructure drives the success of innovation activities.

The purpose of this article is determining the strategic directions and actual conditions, manners and tools for the development of innovative infrastructure in the regions of Russia.

\section{The Role of Innovative Infrastructure in the Development of Economy}

Innovative infrastructure plays a critical part in the social and economic development of a state. It comes as a connection link between science and technology sector and implementation, development and manufacturing of a high-tech product, together with its' shipment to the market.

Various scientists explored the innovative infrastructure and its' influence on the development of economy. They all gave different definitions of the innovative infrastructure and described it as a driver for the development of a region:

- a "key" to the civilized establishment of innovative business activity, securing stability and reliability of an economic system, together with its' effective and long-term development (Shukshinov, Vzyatyshev, \& Romankova, 2006);

- the aggregate of organizations contributing to the implementation of innovative projects, including the provision of the management, materials and technology, finance and IT counsel, human resources, consulting and organizing services (The Federal Law, 2013);

- the aggregate of innovative activity establishments (scientific research institutes, higher education facilities, innovation and technology centers, technology parks, special economic zones, common use centers, development funds and other special-purpose organizations), resources and tools, providing materials and technology, finance and IT counsel, organizing, methodological, consulting and other services for the innovative activities (Moscow Administration of Russian Federation, 2008; Dmitriev, Filimonova, \& Fraymovich, 2014);

- the aggregate of institutions, organizations and individuals securing the beneficial opportunities and environment for production and implementation of the innovation. That includes private individuals and legal entities providing innovative manufacturers with appropriate assistance in finance, technology and materials, organizing, consultancy, IT and other areas (Nefediev, 2011);

- a complex of interlinked structures providing services for implementation of the innovative activities (I. Korshenko, O. Korshenko, \& Kuznetsov, 2013).

Given the definitions suggested by various authors, the essential characteristic of the innovative infrastructure of a region can be determined as follows.

Innovative infrastructure is the aggregate of the interlinked and complementary special-purpose and non-specialized objects in a country or a region, combined with the respective management systems that are required for the efficient implementation of the innovative activities.

The special-purpose objects of an innovative infrastructure can be determined as any organizations that own or attract the economic resources for support and encouragement of the innovative processes in a country or a region.

The non-specialized objects of an innovative infrastructure include the organizations that are fully or partially involved in the innovative processes for the purpose of implementation of the certain economic, social, ecologic or other objectives.

The government supports the development of innovative infrastructure; all kinds of projects are being implemented - such as the status of a national research university that has been granted to 29 universities. 8.42 billion rubles have been subsidized for all developing innovation projects in 2009 - 2010.

Furthermore, there is a governmental support of the cooperation between businesses and higher education facilities with the following development of the innovative infrastructure within such facilities (the Federal Treasury subsidized approximately 90 billion rubles for this purpose in 2010 - 2012) (Ministry of Economic Development of Russia \& Ministry of Education and Science of Russia, 2011). 
The innovation processes of the Russian economy feature some contradictory patterns. On the one hand, there is a tremendous potential of the fundamental and the industrial sciences. On the other hand, the level of applying the scientific research to the actual implementation of innovation is fairly low.

According to the Concept of the long-term social and economic development of Russian Federation (Ministry of Economic Development of Russia, 2008) the share of Russia in the global market of high-tech products and services will have reached no less than $5-10 \%$ in 5-7 and more economy sectors by 2020 (nuclear energetics, aviation, space technology, specialized shipbuilding industry, particular niche software markets).

The share of export of the named Russian products in the global volume of export of the high-tech products will have increased to $2 \%$ by 2020 (compared to $0.8 \%$ in 2012). The GVA of the innovation sector within the GDP will have amounted $17-20 \%$ by 2020 (compared to $12-14 \%$ in 2012). The share of innovative production in the general volume of industrial production will have grown to $25-35 \%$ (compared to $12-14 \%$ in 2012).

The internal costs for research and development will have raised to $2.5-3.0 \%$ of GDP in 2020 (compared to $1.16 \%$ in 2012), more than half of which - at the expense of the private sector. The education spending covered by the state and private donors will have amounted to $6-7 \%$ of GDP in 2020 (compared to $3 \%$ in 2012), the health-care spending - to $6.7-7 \%$ of GDP in 2020 (compared to $3.9 \%$ in 2012), which will allow the accelerated development of a human potential (Federal State Statistics Service, 2013).

Considering this, it may be noted that the development of the innovative infrastructure is the first step and the fundamental part of securing the sustainable and effective cooperation between science, education and manufacturing, given the Russian economy's transition to the innovative development pattern.

Therefore, the strategic goal of development of the innovative infrastructure of a region comprises the reasonable location and effective implementation of the science and technology potential, the establishment of its' structure, the expansion of the science and technology's input in the development of the state economy, providing a better efficiency and competitiveness of the innovative products.

The challenges for development of the innovative infrastructure are proposed as follows:

- Securing (as the first step - creating) an environment for technology transferring and commoditization, which would provide occupation, retaining and acknowledgement for the outstanding scientists, college professors and businesspersons;

- $\quad$ Providing business entities with knowledge and opportunities for the intellectual property management, so they are capable of generating the intellectual solutions;

- Increasing quality and volume of education and research within the manufacturing sector, cooperation with science;

- Establishing the multi-purpose education and science centers within the universities, which would allow involving both professors and students into the innovation processes with the help of science and laboratory facilities of the scientific research institutes and attracting new intellectual resources to the scientific research institutes;

- Activating the incorporation of innovative technology within the Russian companies and establishing a network of innovation business nurseries for the support of new companies focused of such technology - via licensing, prototyping and capitalization of technology in the new companies' shares;

- Securing the additional revenue for the support of research and obtaining new knowledge - via the amortization of intellectual property, license sales, license payments and distribution of dividends on shares in new companies;

- Attracting, educating and retaining the qualified personnel essential for achieving the strategic, operational and business goals of the innovative development of Russian economy;

- Establishing and developing the relevant partnerships, consortiums and unions for the multiplication of volume and diversity of the offered services;

- Introducing new business development methods into the Russian practices - such as the establishment of innovation companies with the purpose of the following reselling, subject to their success.

Therefore, position and problems of development of the innovative infrastructure in Russia demonstrate its' underestimation as a strategic factor of the implementation of the market reformation and the upgrade of economy development in general. 


\section{Methodology of Research}

In order to provide the strategic directions for development of the innovative infrastructure in regions it is proposed to apply the indicators of the development evaluation. Indicators of development of the innovative infrastructure of the region are presented in Table 2 .

Table 2. Indicators of the development of a regional innovative infrastructure

\begin{tabular}{|c|c|c|}
\hline $\begin{array}{c}\text { Factor defining the } \\
\text { innovative infrastructure } \\
\text { of a region }\end{array}$ & Indicator & Index \\
\hline $\begin{array}{l}\text { Number of sites in a } \\
\text { technology park (NSTP) }\end{array}$ & $\begin{array}{l}\text { 1. Number of patents and licenses in a region (NPL) } \\
\text { 2. Number of experimental development subjects (NEDS) } \\
\text { 3. New knowledge that can be transformed into a commercial } \\
\text { product (NK) }\end{array}$ & $\begin{array}{c}\mathrm{NSTP}= \\
(\mathrm{NPL}+\mathrm{NEDS}+\mathrm{NK}) \times 0.035\end{array}$ \\
\hline $\begin{array}{l}\text { Venture capital funding } \\
\text { of innovation in a region } \\
(\mathrm{VCF}) \text {, million rubles }\end{array}$ & $\begin{array}{l}\text { 1. Cost of feasibility report arrangements and financing of the } \\
\text { relative research (CFR) } \\
\text { 2. Cost of industrial design of a product, manufacturing of the } \\
\text { experimental batch (CIDP) } \\
\text { 3. Live capital for the support of a start-up (LCSS) } \\
\text { 4. Transitional financing for initial public offering arrangements } \\
\text { (TFIPO) }\end{array}$ & $\begin{array}{l}\mathrm{VCF}=(\mathrm{CFR}+\mathrm{CIDP}+\mathrm{LCSS}+ \\
\mathrm{TFIPO}) \times \text { number of projects } \\
\text { selected by venture capital } \\
\text { fund in a region }\end{array}$ \\
\hline $\begin{array}{l}\text { Non-state funding of } \\
\text { innovation (NF), million } \\
\text { rubles }\end{array}$ & $\begin{array}{l}\text { 1. Credit banks funding innovation (CB) } \\
\text { 2. Non-state pension funds financing innovation (NPF) } \\
\text { 3. Insurance companies funding innovation (IC) }\end{array}$ & $\begin{array}{c}\mathrm{NF}=(\mathrm{CB}+\mathrm{NPF}+\mathrm{IC}) \times \text { number of } \\
\text { projects }\end{array}$ \\
\hline $\begin{array}{l}\text { Data and expert advisory } \\
\text { support of the innovation } \\
\text { activity (DEAS) }\end{array}$ & $\begin{array}{l}\text { 1. Volume of consulting, auditing, informational, analytical and } \\
\text { other services provided by all objects of innovative } \\
\text { infrastructure (VCAIAS) }\end{array}$ & DEAS $=$ VCAIAS \\
\hline $\begin{array}{l}\text { Human resources for the } \\
\text { innovative activity (HR), } \\
\text { persons }\end{array}$ & $\begin{array}{l}\text { 1. Number of human resources in science performing scientific } \\
\text { research, scholastic, consulting, informational and other work } \\
\text { associated with organization and support of innovative activities } \\
\text { and providing analysis and inspection of innovation projects } \\
\text { (NHRC) }\end{array}$ & $\begin{array}{c}\mathrm{HR}=\mathrm{NHRC} / \text { required number } \\
\text { of human resources for the } \\
\text { innovative activity }\end{array}$ \\
\hline
\end{tabular}

As long as the innovative infrastructure is a system, the efficiency of its' performance is determined not only by the existence of infrastructure institutes (technology parks, innovation commoditization centers, venture capital funds etc.), but also by the comprehensive intercommunication between them - the absence of which in the Russian economy results in the extremely low efficiency of investment in the establishment of innovative infrastructure of a region.

The organization and mechanics of the extended implementation of a science and innovation process has to be established in its' entirety, not in parts of its' potential. In other words, in order to ensure the growth of competitiveness of a country and a region, the economy has to be constantly focusing on the search, implementation and introduction of innovation - the innovative development pattern.

In general, the essential benchmark would be combining the science and innovation campaigns within all economy and social areas. The primary requirement of the establishment of an innovative infrastructure is a practical and profound agreement between science, technology, society and authorities and setting up the new relationship between science - the key factor of innovative development - and state. However all these enhancements must be based on the mutual obligations of authorities and science, research organizations and scientists, on a new social contract with mutual commitment and not just requests on the subsidies from the state treasury.

\section{Results}

The proposed indicators of development of a region's innovative infrastructure as an example can be applied to Vladimir region. In accordance with Vladimir region's strategy of social and economic development for the following 18 years, the share of innovative products is supposed to have reached $35 \%$; the share of companies focusing on innovation in all active companies of the region is supposed to have reached $40 \%$ (Administration of Vladimir region, 2012). Therefore, a predictive evaluation of the level of an innovative infrastructure development becomes a massive measure of its' growth (Table 3).

The recommended values have been calculated basing on the statistic data of Tomsk region since it has been voted as the leading region in terms of innovative development. 
Table 3. Recommended values for the indicators of the regional innovative infrastructure development

\begin{tabular}{lc}
\hline Factor defining the innovative infrastructure of a region & Recommended value \\
\hline Number of sites in a technology park (NSTP) & 29 \\
Venture capital funding of innovation in a region (VCF), million rubles & 26.3 \\
Non-state funding of innovation (NF), million rubles & 14 \\
Data and expert advisory support of the innovation activity (DEAS) & 589 \\
Human resources for the innovative activity (HR), persons & 2478 \\
\hline
\end{tabular}

In order to secure the effective development of the innovative infrastructure of Vladimir region, the international cooperation in science and technology has to be strengthened. The development of this course should be focused as follows:

- with regards to fundamental, exploring and applicative research - on the implementation of the massive international cooperative campaigns;

- with regards to innovations - on the cooperative activities and commoditization of the science and technology achievements in both internal and external markets, combined with the cooperative effort concerning the attraction of purpose-oriented subsidies and direct foreign investment.

In order to provide a solution for these problems, it's essential to develop a training system for the international level managers of innovative activities and abide by the rules of securing the patent (or other) protection of the intellectual property.

\section{Courses of Development of the Innovative Infrastructure of the Region}

Small businesses need support, especially at the stage of their establishment. Technology parks and innovation business nurseries helping the startuppers to maintain their projects during one of their most vulnerable stages of development are very common worldwide. How many sites in a technology park or an innovation business nursery are required in order to offer a solution for the development of a small innovation business in a region?

There is no simple answer to this question. Every region takes a decision on the number of sites in a technology park or innovation business nurseries on its' territory, depending on the needs and potential plans for the development of its' economy. The authors suggest estimating the number of sites in a technology park required for a region using the following calculation: the volume of new knowledge that can be transformed into a commercial product multiplied by $3.5 \%$.

In accordance with the US estimations, only $10-30 \%$ of ideas can become patented inventions, and just 0.5 $3.5 \%$ of those are recoupable to some extent. These estimations also suggest that 58 ideas on average are required for an industrial establishment in order to secure a successful performance in the market with just one product.

The funding sources for an innovative infrastructure can be both state and private. The primary funding for an innovative infrastructure should be coming from the state treasury via various target programs and tenders.

In accordance with the international practice, the involvement of the private sector of economy is prevailing in the establishment of a finance innovative infrastructure. Venture capital funds play a critical part in the development of innovative infrastructure of a region. Given that, the optimization of this factor in terms of the specified indicators has been proposed in Table 2.

One of the key factors constraining the dynamic development of a finance infrastructure in Russia is a total absence of the instruments for the non-state pension funds and insurance companies, caused by the law restrictions for equity investment in venture institutions and by the potentials risks of negative earnings.

The optimization of the non-state funding of an innovation (pension funds, insurance companies and commercial banks) will encourage the delivery of not only financial, but also technological support by means of the broad access to material, human and information resources.

An innovative infrastructure includes the following sub-systems: data support, tooling backup (hardware and software complex for the automation of all processes), design and technology support, manufacturing support, inspection and certification of innovation projects, monitoring and promotion of an innovation in the regional, interregional and international markets, coordination and management of the innovation activity and its' financial and economic maintenance, training for the human resources.

More specifically, the optimization on an innovative infrastructure offers: 
- working out the guidelines for setting up the purpose-oriented databases using a competitive technology, including the ones of dual purpose;

- establishing a regional databank and knowledge pool (with the most recent technology, science institutions, development establishments and manufacturing facilities);

- developing, maintaining and constant enhancing of the information model of a region and the model of its' development;

- monitoring the innovative investment activity in the industry sectors and companies;

- issuing newsletters, leaflets, brochures and other periodical publications;

- arranging exhibitions, seminars, conferences, presentations, innovation exchanges;

- providing marketing support for the competitive product, from the demand of research and development to the studies of new technology market.

The optimization of human resourcing of an innovative infrastructure of a region is implemented as follows:

- determining the necessary and sufficient number of members of a subdivision basing on the functional requirements and amounts of work;

- determining the qualifications required for the certain positions and job roles;

- recruiting and selecting staff for the vacant positions in accordance with the required qualifications and professional abilities of the candidates, combined with their work-related personal, psychological and social characteristics.

Model building is the most popular approach for the forecasting of social and economic processes. A model is built in a way that allows reflecting the characteristics of the analyzed object and their interaction in terms of the purpose of research. Therefore, the problem of quality of such reflection - the model adequacy - is appropriate to be solved only concerning a certain purpose. Out of all applicable methods, the mathematical model approach is the key one, as it allows justification and efficiency of a forecast to the maximum extent.

Therefore, when solving a problem of effective social and economy system management, it is essential to thoroughly review the forecasting challenge.

\section{Conclusion}

The encouragement of innovative activities is quite literally the highest priority course of the economic policy of the state, as long as the level of science and technology development mainly influences on the long-term strategic advantages of a country; the potential development of a state largely depends on the innovative infrastructure. One of the priority courses of utilization of an innovative infrastructure is the development of small and medium businesses.

The innovation processes of the Russian economy feature some contradictory patterns. On the one hand, there is a tremendous potential of the fundamental and the industrial sciences. On the other hand, the level of applying the scientific research to the actual implementation of innovation is fairly low. Therefore, establishing a comfortable environment is one the most important goals within the implementation of the innovation support.

The challenge of establishment of an effective innovative infrastructure is of a complex nature, it requires the consolidation of state's and regional resources combined with the need of attraction of the significant private investments in this economy sector.

\section{References}

Administration of Vladimir Region. (2012). Strategy for the socio-economic development of the Vladimir region for the period up to 2027. No.37.

Bortnik, I., Zinov, V., Sorokina, A., \& Kotsyubinsky, V. (2013). Questions of reliability of statistical information regarding the innovation activities in Russian Federation. Innovations, 10(180), 10-17.

Dmitriev, J., Filimonova, N., \& Fraymovich, D. (2014). Optimization of the Regional Investment Resources. Life Science Journal, 11(7), 89-95. Retrieved from http://www.lifesciencesite.com/lsj/life1107/012_24039life 110714_89_95.pdf

Federal State Statistics Service. (2013). Science, innovation and information society. Retrieved from http://www.gks.ru/

Filimonenkova, H., Kupreenko, U., \& Shvarova, E. (2014). For the international comparisons of 
scientific-technical and innovative development of the countries worldwide with the definition of the place of Russia in the modern global economy. The Scientific Community of Students of the XXI Century, 7(22), 58-63.

Korshenko, I., Korshenko, O., \& Kuznetsov, P. (2013). Infrastructure for the development of the strategy types for the regional innovative development. Innovations, 10(180), 51-57.

Ministry of Economic Development of Russia. (2008). Concept of the long-term socio-economic development of Russian Federation for the period up to 2020. Retrieved from http://www.consultant.ru/document/ cons_doc_LAW_90601/?frame=1

Ministry of Economic Development of Russia \& Ministry of Education and Science of Russia. (2011). Strategy of innovative development of Russian Federation for the period up to 2020. Retrieved from http://www.garant.ru/ products/ipo/prime/ doc/70006124/\#ixzz2trOJdpQX

Moscow Administration of Russian Federation. (2008). The municipal complex target program of the establishment of an innovation system in the city of Moscow in 2008-2010. No. 781.

Nefediev, A. (2011). Innovative Infrastructure. Creative Economy, 10(58), 42-48. Retrieved from http://www.creativeconomy.ru/articles/13356/

Shukshinov, V., Vzyatyshev, V., \& Romankova L. (2006). Innovative education: Ideas, principles, models. Moscow, Russia: Prosveschenie.

The Federal Law. (2013). Science and the state scientific-technical policy. No. 127.

\section{Copyrights}

Copyright for this article is retained by the author(s), with first publication rights granted to the journal.

This is an open-access article distributed under the terms and conditions of the Creative Commons Attribution license (http://creativecommons.org/licenses/by/3.0/). 